\title{
The Translatability of Metaphor in Eliot's The Waste Land: A Comparative Approach
}

\author{
Mohamed Ayed Ibrahim Ayassrah ${ }^{1} \&$ Mohd Nazri Latiff Azmi ${ }^{1}$ \\ ${ }^{1}$ University Sultan Zainal Abidin (UniSZA), Terengganu, Malaysia \\ Correspondence: Mohamed Ayed Ibrahim Ayassrah, University Sultan Zainal Abidin (UniSZA), Terengganu, \\ Malaysia. E-mail: ayasrah@gmail.com
}

Received: October 2, 2019 Accepted: October 23, 2019 Online Published: November 14, 2019

doi:10.5539/ells.v9n4p53 URL: https://doi.org/10.5539/ells.v9n4p53

\begin{abstract}
There is an obvious gap in studying the translatability of metaphor in modern English poetry, particularly in Eliot's The Waste Land. Furthermore, it is observed that most previous studies about metaphor are in and for English, and only few ones have tackled the translatability of metaphor into another language. However, the current study aims to explore this phenomenon in Eliot's The Waste Land and three of its Arabic translations. All metaphors of The Waste Land and its three translations are identified, studied and classified into juxtaposed tables to facilitate the comparative process. Then, an assessment of each translation is made to be compared to the original text and the other translations. This comparison aims at identifying the translatability of metaphor in The Waste Land, the most and least used strategy and how the three translators have dealt with the original text. The study also shows that the three translators could translate most of Eliot's metaphors into Arabic analogous metaphors; Lu'lu'ah uses this strategy the most and Raghib the least. Furthermore, the strategy of paraphrasing the metaphor is used more than the second one (11 cases). Finally, this study suggests three recommendations for further upcoming studies. The first one is: Conducting a comparative study on using metaphor in the spoken languages or dialects of two different societies (the Jordanian and British, for instance). The second is: Exploring this phenomenon in students' everyday language; and the third is: Investigating the ability of English language students in rendering metaphor from English into Arabic.
\end{abstract}

Keywords: literary works, metaphor, source text, simile, target text, translation

\section{Introduction}

Metaphor is extensively employed in literary works generally and in modern English poetry particularly. Eliot's The Waste Land, for example, is considered a fascinating-metaphorical poem. However, it is a fantasy to try to understand this poem without grasping its ambiguous metaphorical scenes. Accordingly, translating such complex phenomenon requires a qualified translator, with poetic talent in both English and Arabic poetry, to be able to transfer the original poetic effect and spirit. All of that may make translating these poetic metaphors a challenging duty for Arabic translators which leads to a clear gab in investigating the translatability of metaphor as a cross-cultural phenomenon in modern poetry. Newmark (1981) claims that translating metaphor is considered a complex issue.

\subsection{Previous Related Studies}

Obeidat (1997) studies translating metaphor in Arabic modern poetry and what makes this process easy, difficult or impossible. The results of this study show that metaphors of Arabic modern poetry are mostly translatable into English, but that requires recreating the alike cultural experience in the target language. It is discovered that some metaphors are easy to be translated because they are cross-cultural ones. Finally, it is revealed that a few metaphors are not translatable because the target language does not have a parallel expression for the original metaphorical expression.

Al Salem (2014) focuses on translating metaphor from Arabic into English in ten selected poems of Mahmoud Darwish. He states that modern Arabic metaphor, in modern poetry, is usually mistranslated and so misinterpreted in the target language; furthermore, this affects the style, the scene, the theme and the meaning of the original metaphorical expression. The study compares several translators in the strategies of dealing with translating Arabic metaphor in modern poetry. In conclusion, the study shows the translators use several strategies to translate 
the Arabic metaphor, but the most used one is reproducing the metaphorical scene in the target language metaphorically. The study also asserts the vital role of the translator in transforming the core meaning and feeling of the metaphor between the two cultures. Finally, it is shown that there are some challenges that face the translators such as: recognising the original metaphorical expression and finding the suitable equivalent in the target language.

Abdal and Yaman (2017) try to examine translating poetic metaphors. He adopts the Conceptual Metaphor Theory of Lakoff and Johnson to analyse Birhan Keskin's poems. The study indicates that translating metaphor has to have the translators' fingerprints to make them comprehensible in the target language. Moreover, the poetic style plays a crucial role in obscuring translating the poetic metaphors. Finally, the study claims that translating poetic metaphors is a real challenge to translators.

Manipuspika (2018) has studied Lauren Kate's Fallen novel to explore translating English metaphors into Bahasa language. He has attempted to explore the strategies used by translators to deal with this figure of speech. At first, he has assumed that metaphor is mostly untranslatable because it is associated with hidden meaning. Nevertheless, his study has finally reached the result that it is translatable in apportion of about $38 \%$ of the original metaphors.

\subsection{Objectives and Questions of the Study}

The current study aims at answering the next questions:

1) How frequent are metaphors employed in The Waste Land and its Arabic translations?

2) What are the main pitfalls and shortcomings faced by translators when rendering English poetic metaphors into Arabic?

3) To what extent are metaphors equivalent in the ST and TT?

\subsection{Methodology}

Modern English poetry is chosen to be the scope of the study as it is rich in metaphor. However, Eliot's Waste Land is selected because of its attractiveness and excellent reputation in the Arab world. Actually, many Arab poets, critics and translators were fascinated by Eliot's work that some called for resisting the vast effects of Eliot's work on Arabic writers (Ayasrah \& Azmi, 2019). Furthermore, after searching in Eliot's poetic works, it is found that his poem The Waste Land is the most appropriate one for such research since it does not only have many metaphorical expressions but also a lot of literary images as well. Moreover, this poem has attracted many Arab translators, scholars and critics to study and analyse it.

It is worth mentioning here that The Waste Land and its translations are convenient for this study because the research is conducted on the analysis of the text, which is why the poem and its translations are convenient for this study. Care is also taken to choose a text that is both appropriate and is as comparable as possible in the two languages. Finally, three translations are selected as the material of analysis, namely Lu'lu'ah (1980), Raghib (1987), and Yusuf (2008) (modernitysite.wordpress.com), (mnaabr.com) and (abdelhay-eliot.blogspot.com/) respectively.

The first translator of The Waste Land is Abdul Wahid Lu'lu'ah who was born in 1931 in Mosul/Iraq. He is a university professor, critic, writer and translator. He speaks English, Spanish, French and Germany besides Arabic. He received the Bachelor degree in English language from Iraq in 1952, a Master degree of English literature in 1957 and a PhD in English literature in 1962 from the United States. Since then he has been working in many universities in Iraq, Jordan and other Arab countries. He published more than 45 books about literature, criticism and translation. The first edition of his translation of The Waste Land appeared in 1980, the second in 1986 and the last in 1995 (Nsiri, 2018).

The second translator is Nabeel Raghib, who is an Egyptian philosopher, writer and critic. Born in Egypt in 1940, he received a Bachelor degree in English literature in Egypt and the Master and $\mathrm{PhD}$ of English literature from England. He worked in many institutes and universities in Egypt. He also worked as a political adviser to the minister of Culture and, then, to the president Anwar Al- Sadat (1975-1981). He wrote more than one hundred novels and books. He translated The Waste Land in 1987 (El-Enany, 2000).

The third translator is Mohammed Abdulhai Sayed Yusuf who is a well-known Egyptian translator who was born in Cairo. In addition to Eliot's Waste Land, he translated several universal works such as "The Indian to His Love", "He Remembers Forgotten Beauty", "The Lamentation of the Old Pensioner", "The Sorrow of Love" and many others (Abdulla, 2011).

After that, a preliminary analysis is made of the metaphorical expressions used in The Waste Land. Then, the metaphorical expressions are identified by investigating each verse. Next, to distinguish the translated metaphors 
into Arabic, the three Arabic translations are respectively analysed, and all their metaphors are identified and compared to the original text. Then, all of the Arabic and English metaphorical expressions are categorised into juxtaposed groups to ease the process of analysing and comparing the metaphorical texts.

The texts are divided into stanzas to study each metaphorical expression and compare it to its translations easily. These expressions are listed into three domains. The first one includes metaphorical expressions in the source text that are translated to metaphorical ones into the target text. The second contains the cases where metaphors are translated into similes. The third table implicates the cases where metaphor is deleted in the target text. Finally, the final results are summarised and concluded.

\section{Translation: Definitions and Nature}

It is a given axiom that language is similar to a living thing which, from time to time, should grow and develop. Translation is a significant means that has an essential role in such process, besides exchanging knowledge and ideas among different languages. Translation is a wide-open field of knowledge that can be enriched and developed from one side and help languages to be so from the other.

At the early stages of learning translation, many scholars wrongly thought that translation is a mechanical way of a word for word process. Whereas translation is a human linguistic activity, so when translating the source text into a target one, the translator has to transfer not only the words and style but also meanings and ideas. He sometimes has to use rhetorical style to transfer the original thought and language effect. Furthermore, if the source text is translated word for word, we will often get clumsy translation leaving the final product without much effect because it will not convey the exact message intended in the original text. To avoid that, effective translation requires imagination and skills that categorise the human mind, so it is not logical to think of the computer as an efficient independent means of translation (Karpińska, 2017).

Translation is defined differently by many scholars. For example, Nida and Taber (2003, p. 208) define translation as reproducing the message of the original metaphor into an equivalent one in the target text in terms of meaning and style. Translating, for Manfredi (2008) is a process of linguistic formulation where translators re-form the idea of the original speech to the target one. He also belies that translation is a complex, independent type of speech activity that consists of stages such as understanding and interpreting foreign language text and transfer its meaning to another language text.

Besides, Bell, (1991, p. xv), believes that translation is the process of converting a specific text from a language into another. It is also can be transforming some data between two dissimilar languages (Al-Amri \& Abdul-Raof, 2016). Finally, translation, according to Newmark (1991, p. 31), is "Rendering of the meaning of a text into another language in the way that the author intended the text".

Consequently, it can be concluded that the first and foremost purpose of translation is communication and making interaction easier among various nations. The second one could be transmitting some ideas among various languages.

\section{Strategies for Translating Metaphor}

As for the applicable techniques, procedures, or strategies of translating metaphors, many of them were established by scholars and researchers such as Menachem Dagut, Peter Newmark, Den Broeck, Fernández and Prandi, to name but few (Spinolo, 2018).

Newmark and Dagut are among the scholars who played a central role in the first guidelines of translating the metaphorical expressions in literary works. They tackle with metaphor as an independent case regardless of its context (Monti, 2006). Dagut (1987) claims that it is not possible to find an equivalent translation for metaphor in another language since it is an imaginative, mental issue.

Depending on the previous idea, Dagut (1987) infers that the translation of metaphor is a re-creation work that requires a skilful, creative translator to recreate or re-form metaphors which should be linguistically and culturally acceptable within the TL. Nonetheless, he does not negotiate any strategy of rendering metaphors.

Newmark (1981, p. 88) tries to establish a framework of strategies and possibilities of the process of translating metaphor:

(1) Reforming the original metaphor in the TL literally.

(2) Exchanging the metaphor in the original text with a standard metaphor in the target text.

(3) Interpreting metaphor via changing it to simile.

(4) Interpreting metaphor via changing it to simile plus sense. 
(5) changing metaphor into sense.

(6) Dropping it.

(7) Reforming the original metaphor, including its sense.

Den Broeck (1981, p. 74) suggests some strategies of translating metaphor:

1) Translating metaphor literally.

2) Translating the metaphor into another with a different vehicle.

3) Paraphrase the meaning of the metaphor.

As mentioned previously, Dagut, Broeck and Newmark have almost the same point of view about metaphor. However, depending on Broeck and Newark's suggestions about the strategies of translating metaphor, this study has adopted the following possibilities and strategies in order to investigate metaphor translation from English into Arabic:

1) Translating a metaphorical expression into an equivalent one.

2) Translating a metaphorical expression into a simile.

3) Translating a metaphorical expression into a non-metaphorical one; (deleting metaphor).

Depending on these three strategies, all metaphors of The Waste Land were classified into three groups. The first one includes the metaphorical expressions that are translated into equivalent ones. The second includes those which are translated into similes. The third has examples of the ones that are omitted in the TT.

\subsection{The First Strategy: Metaphor into Metaphor}

Initially, through questing almost all cases of the metaphorical expressions in both The Waste Land and its three translations, it is noticed that the three translators could translate most of the metaphorical images used by Eliot in The Waste Land as ST (source text) into metaphorical ones into Arabic translations as TT (target text). This may be attributed to the competence and ability of the translators who dared to translate such a great, complex and obscure poem which is considered by some critics as the greatest poem in the twentieth century.

\subsection{The Second Strategy: Metaphor into Simile}

It is essential to know that both metaphor and simile are thought to be considered related figures of speech which can be found commonly in written or spoken language. Sometimes, differentiating between them confuses some people, since both of them compare two things that are alike in some way. Thus, some metaphors may be translated into similes. However, the apparent difference is that simile consistently makes a comparison using the words "like" or "as". By exploring The Waste Land, it is found that only four metaphorical expressions were translated into similes; all of them are placed in the next table.

\subsection{The Third Strategy: Omitting the Metaphor}

Doubtless, it is impossible to find identical translations of the same text, especially poetry, because not only words and meanings should be translated and transferred, but also both the feelings and the style of the author. Accordingly, for one reason or another, some ST metaphorical expressions are omitted or translated differently into the TT.

\section{The Statistical Analysis}

The subsequent section contains the statistical exploration of the metaphorical expressions of both The Waste Land and the three selected Arabic translations.

Table 1. The three strategies used by Lu'lu'ah

\begin{tabular}{llll}
\hline The strategy & Total cases & Lu'lu'ah & Percentage \\
\hline Metaphor-into-metaphor & 165 & 162 & $98 \%$ \\
Metaphor-into-simile & 4 & 0 & $0 \%$ \\
Deleting metaphor & 11 & 3 & $27 \%$ \\
\hline
\end{tabular}




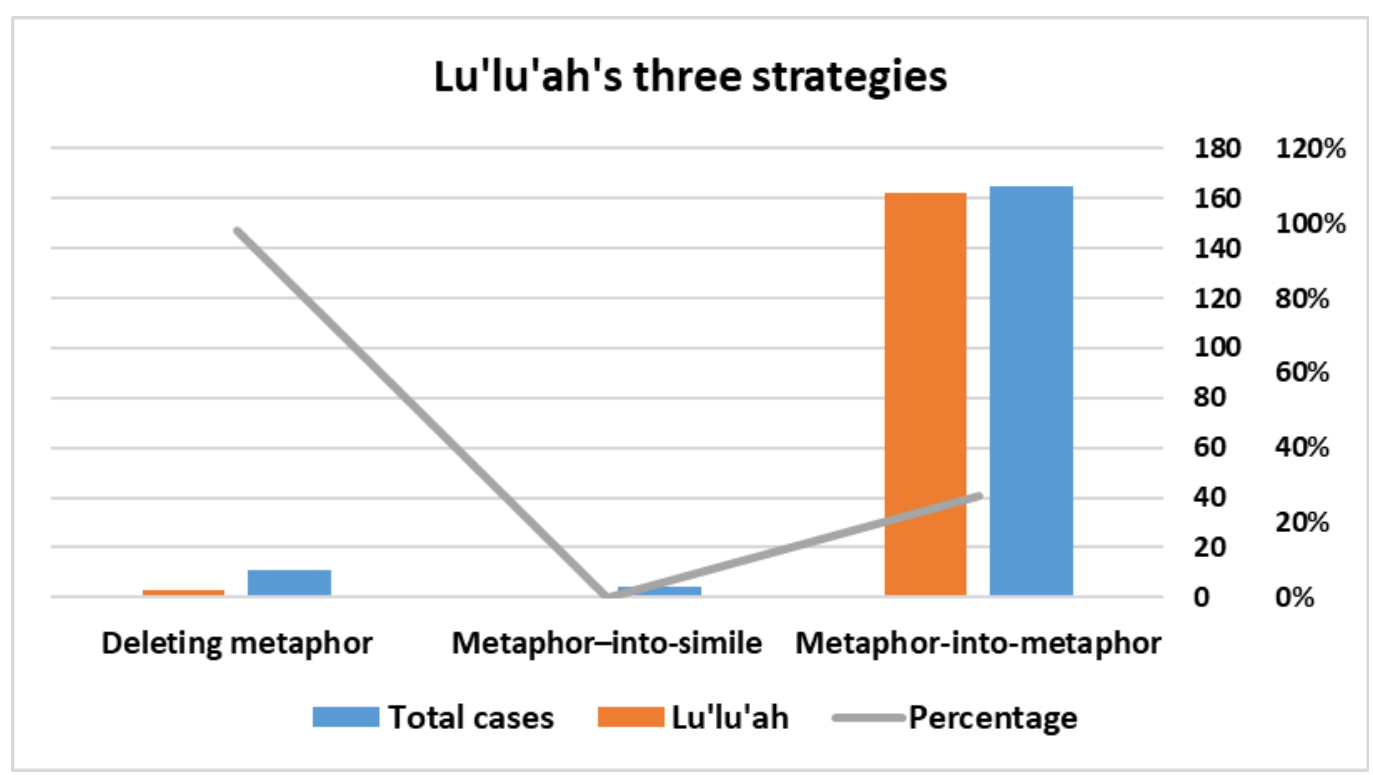

Figure 1. Lu'lu'ah's three strategies

Table 1 and Figure 1 show how Lu'lu'ah employs the strategies of converting the metaphorical expressions identified in the source text. Lu'lu'ah converts 162 metaphors into metaphors in $98 \%$ of the total metaphors in the poem. For the strategy of translating metaphor into simile, Lu'lu'ah does not translate any metaphors into similes; consequently, the percentage is $0 \%$ of the whole four cases of metaphors to simile cases. Lastly, in the strategy of deleting the metaphor, he deletes three metaphors forming $27 \%$ of the whole of eleven similar cases.

Table 2. Raghib's three strategies

\begin{tabular}{llll}
\hline The strategy & Total cases & Raghib & percentage \\
\hline Metaphor-into-metaphor & 165 & 157 & $95 \%$ \\
Metaphor-into-simile & 4 & 1 & $25 \%$ \\
Deleting metaphor & 11 & 7 & $63 \%$ \\
\hline
\end{tabular}

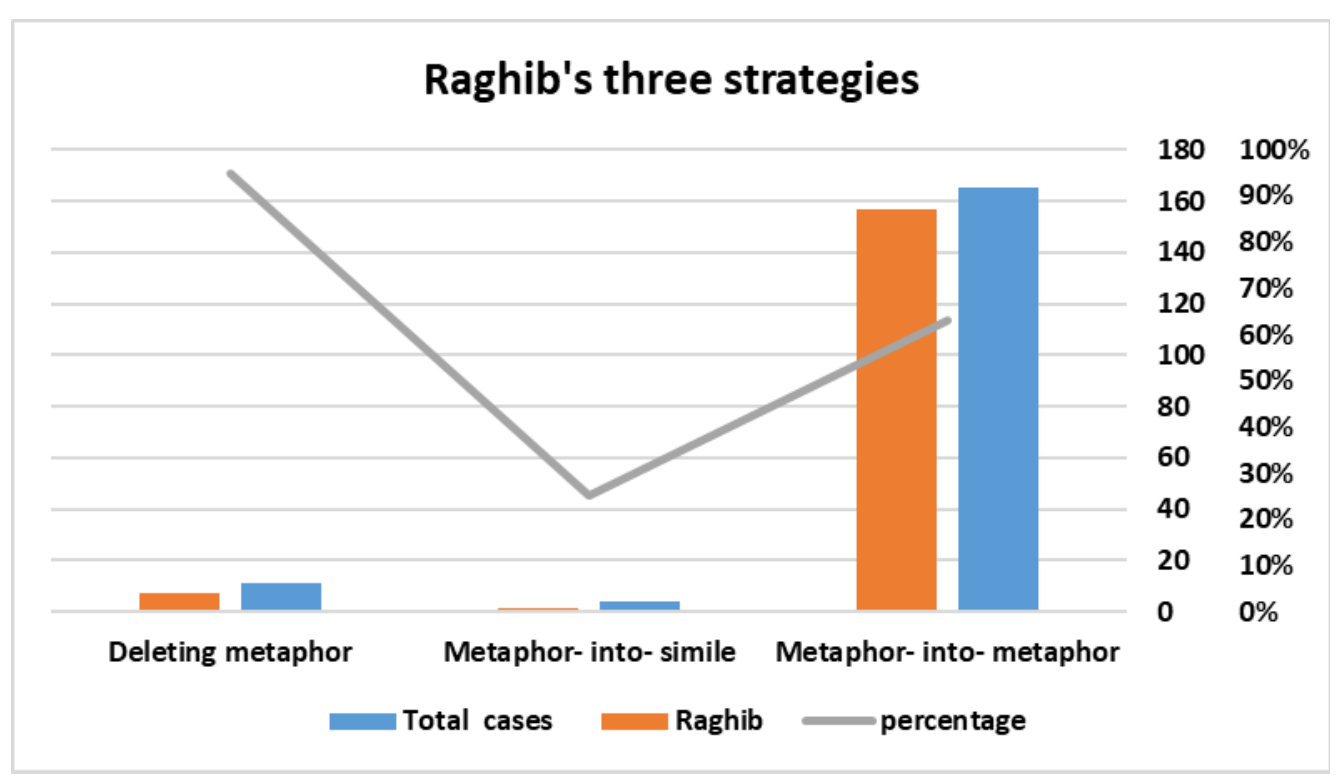

Figure 2. Raghib's three strategies

Table 2 and Figure 2 show that Raghib converts 157 metaphors into metaphors in $95 \%$ of the whole metaphors in 
the poem. In the strategy of translating metaphor into simile, Raghib deals only with one case forming $25 \%$ of the whole four similar cases. Also, in the strategy of deleting the metaphor, he deletes seven metaphors forming $63 \%$ of the whole of the eleven similar cases.

Table 3. Yusuf's three strategies

\begin{tabular}{llll}
\hline The strategy & Total cases & Yusuf & percentage \\
\hline Metaphor-into-metaphor & 165 & 161 & $97.5 \%$ \\
Metaphor-into-simile & 4 & 3 & $75 \%$ \\
Deleting metaphor & 11 & 1 & $9 \%$ \\
\hline
\end{tabular}

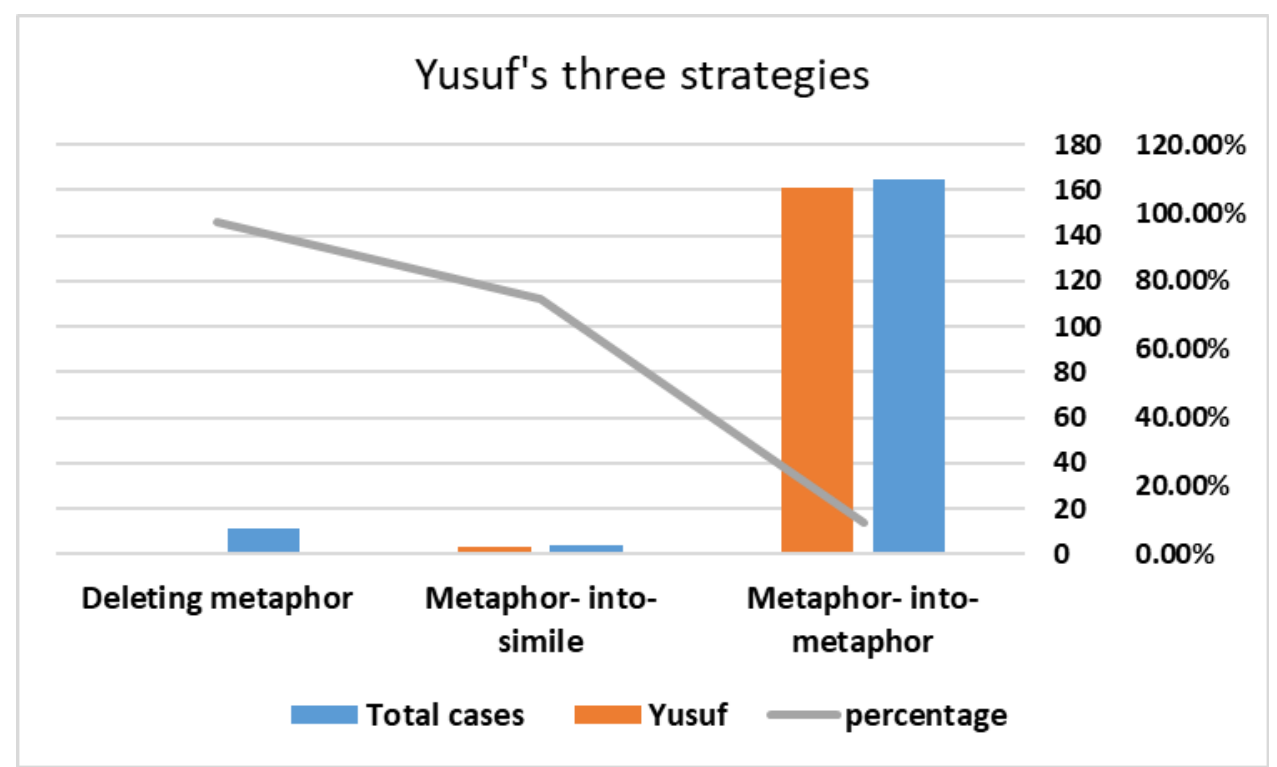

Figure 3. Yusuf's three strategies

Table 3 and Figure 3 show that Yusuf converts 161 metaphors into metaphors in 97.5\% of the whole metaphors in the poem. For the strategy of translating metaphor into simile, Yusuf deals with 3 cases, so the percentage is $75 \%$ of the whole four similar cases. Likewise, in the strategy of deleting the metaphor, he deletes only one metaphor, forming $9 \%$ of all the 11 similar cases.

Table 4. The three translators

\begin{tabular}{lllll}
\hline The strategy & Total number & Raghib & Lu'lu'ah & Yusuf \\
\hline Non metaphor-into-metaphor & 29 & 14 & 6 & 9 \\
Percentage & $100 \%$ & $42 \%$ & $21 \%$ & $31 \%$ \\
\hline
\end{tabular}




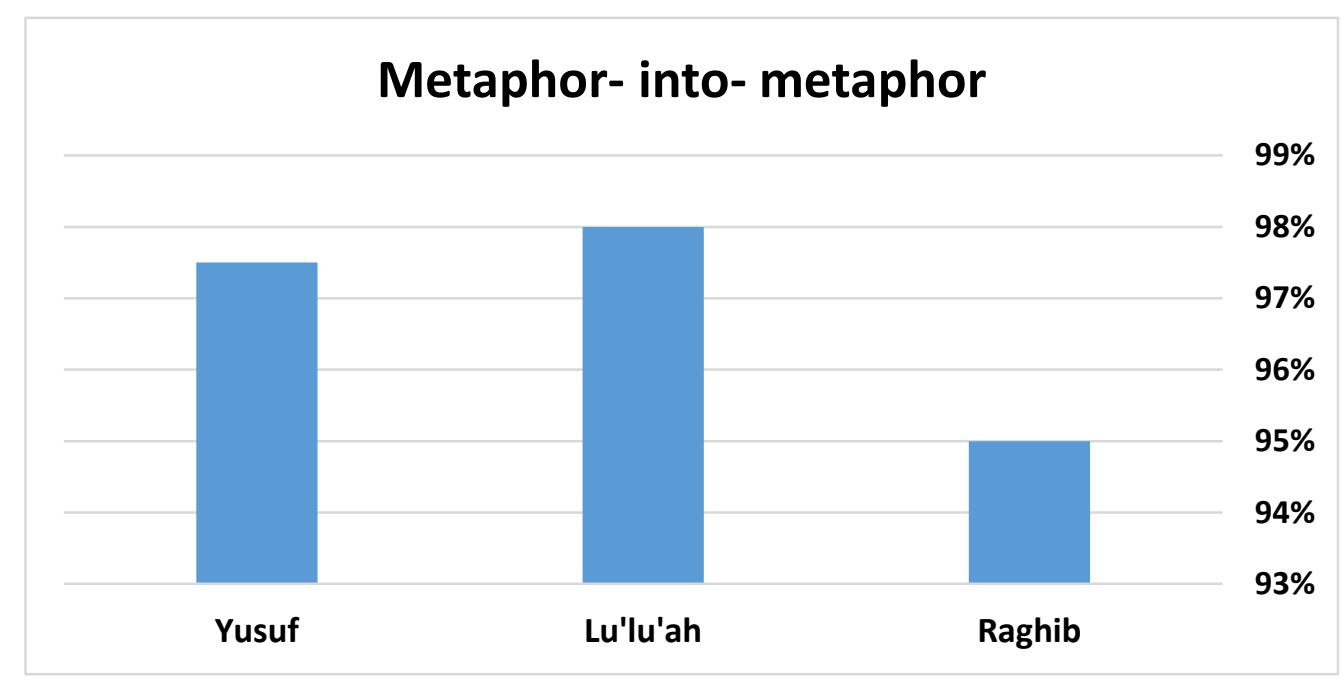

Figure 4. Metaphor-into-metaphor by the three translators

Table 4 and Figure 4 show that Raghib translates 14 non-metaphorical expressions of 29 cases into metaphorical ones. The percentage is 42 , which is the highest. Lu'lu'ah uses this strategy in 6 of 29 cases. The percentage is 21 . While Yusuf transacts 9 of 29 cases by following this strategy in a percentage of 31 . These statistics show that Raghib uses this strategy more than Yusuf and Lu'lu'ah. This result may be attributed to his excellent background in Arabic poetry which is full of metaphors. On the other hand, Lu'lu'ah uses the same strategy less than Yusuf and Raghib. He might have adopted this strategy to avoid distorting the original text as hard as possible.

Table 5. A comparison of the three translators

\begin{tabular}{llll}
\hline The strategy & Raghib & Lu'lu'ah & Yusuf \\
\hline Total number of metaphors & 165 & 165 & 165 \\
Metaphor-into-metaphor & 157 & 162 & 161 \\
Metaphor-into-simile & 1 & 0 & 3 \\
Deleting metaphor & 7 & 3 & 1 \\
\hline
\end{tabular}

Table 6. A comparison of the percentages of three translators

\begin{tabular}{llll}
\hline The strategy & Raghib & Lu'lu'ah & Yusuf \\
\hline Total number of metaphors & $100 \%$ & $100 \%$ & $100 \%$ \\
Metaphor-into-metaphor & $95 \%$ & $98 \%$ & $97.5 \%$ \\
Metaphor-into-simile & $25 \%$ & $0 \%$ & $75 \%$ \\
Deleting metaphor & $63.63 \%$ & $27.27 \%$ & $9 \%$ \\
\hline
\end{tabular}




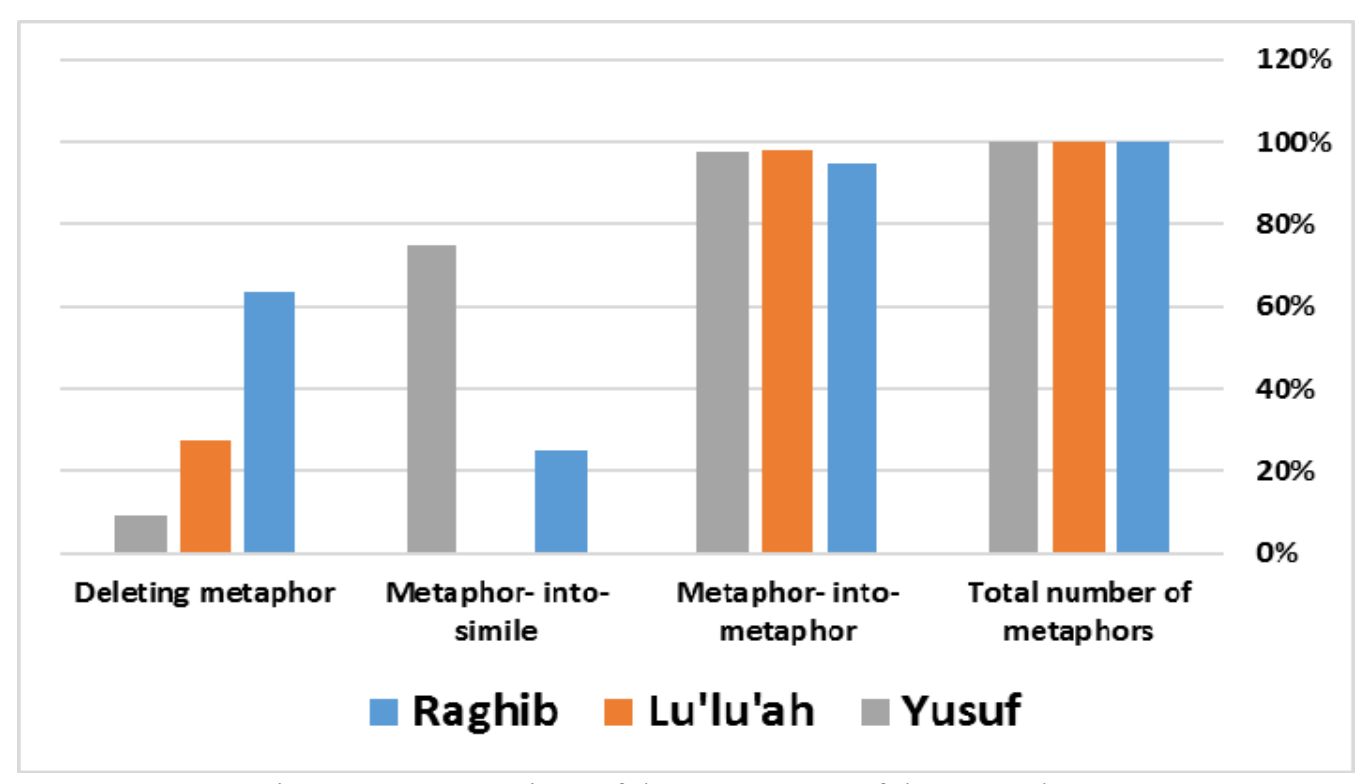

Figure 5. A comparison of the percentages of three translators

Tables 5 and 6 and Figure 5 show the three strategies used by the three translators and the percentage of each one. They reveal that the strategy of converting metaphor into metaphor is used mostly by Lu'lu'ah; 162 , that is $98 \%$ of the total number 165 metaphors, but he does not use the strategy of translating metaphor into simile at all. This result may be attributed to his try to keep a similar pattern of the target language. Raghib, however, is the one who uses the strategy of converting metaphor to metaphor the least times, and at the same time, he uses the strategy of deleting metaphor the most in $63 \%$. Raghib might believe that manipulation with metaphors does not distort the effect of the ST. Finally, it is noticed that Yusuf uses the strategy of translating metaphor into simile the most in a percentage of $75 \%$ of the four cases used in the TTs. He might have believed that converting those cases into simile is more effective and comprehensible.

\section{Conclusions}

It is axiomatic that translating such sensitive metaphorical expressions requires a translator equipped with poetic talent in both English and Arabic poetry to be able to transfer the poetic spirit. However, the thesis analyses the strategies of translating metaphor from English into Arabic by studying The Waste land versus its Arabic translation. Generally, the analysis shows that the three translators translate most metaphors by using the technique of reproducing the same metaphorical images used in the original text, i.e. translating ST metaphors into TT analogous metaphors. It is found that Lu'lu'ah uses this strategy the most and Raghib the least. Also, the three translators rarely use the strategy of converting metaphors into simile (4 cases only). Moreover, the third strategy, deleting the metaphor and paraphrasing its meaning, is more common than the second strategy (11 cases). Depending on the statistics, one may conclude that the strategy of translating metaphor into metaphor is preferred because it is more implicit and less risky.

The research questions that are now re-mentioned here, paired with the answers depending on the results of the study.

1) How frequent are metaphors employed in The Waste Land and its Arabic translations?

The study shows that there are 165 metaphors in the English text, this forms around $38 \%$ of the total 432 verses. In contrast, the Arabic texts contain 178 metaphors with about $41 \%$. This result may indicate that the phenomenon of metaphor is more widely used or preferred in the Arabic language. Finally, the analysis reveals that almost each of the three lines of The Waste Land should contain a metaphor, and this emphasises the importance of metaphor as a means of composing modern poetry.

2) What are the main pitfalls and shortcomings faced by translators when rendering English poetic metaphors into Arabic?

Translating poetry is risky and different from translating other texts, in which keeping the same effect of the ST is not an easy task to fulfil. However, this research detects that poetical metaphorical expressions in modern English poetry are generally translatable into Arabic though that translators sometimes tend to omit metaphor or translate it 
into a simile. Also, they may face stumbling blocks; the way to maintain rhythm, rhyme, spirit and the style of the poem is unpaved and thorny.

3) To what extent are metaphors equivalent in the ST and TT?

All metaphors in both the English text and its Arabic counterparts were observed and analysed in the study. Generally, it appears that most of the metaphorical expressions of the ST fit into the TTs; this is may be attributed to the universality of Eliot's metaphorical expressions. However, it is almost impossible to translate a text precisely by different translators. Thus, many metaphorical expressions of The Waste Land were translated differently into Arabic by the three translators.

To conclude, the analysis has shown that:

1) Poetical, metaphorical expressions are translatable in most cases.

2) The three translators show high efficiency in translating most of the metaphorical expressions successfully.

3) The translation, which is the most correspondent to the ST was Lu'lu'ah's and the least was Raghib's. In other words, the former achieves the principle of fidelity. This translational practice (Lu'lu'ah's) may be attributed to his mastery of cross-linguistic and cross-cultural discrepancies in both Arabic and English.

4) The strategy of converting metaphor into metaphor is the most widely used among the strategies used by the translators.

5) The strategy of converting metaphor to simile is the least frequent: it is not used more than four times.

\section{Recommendations for Future Research}

Translating metaphor in modern poetry is considered as an active- vital field to be researched so that more research on it is still needed. This study suggests three recommendations for further upcoming studies. The first one is: Conducting a comparative study on using metaphor in the spoken languages or dialects of two different societies (the Jordanian and British, for instance). The second is: Exploring this phenomenon in students' everyday language; and the third is: Investigating the ability of English language students in rendering metaphor from English into Arabic.

\section{References}

Abdal, G., \& Yaman, B. (2017). English translations of Birhan Keskin: A metaphor-based approach to poetry translation. LITERA, 27(2), 45-63. https://doi.org/10.26557/iulitera.364786

Abdelhay, R. (2011). Retrieved from http://www.abdelhay-eliot.blogspot.com/

Al-Amri, B., \& Abdul-Raof, H. (2016). Translation in teaching and learning a foreign language: A methodological approach. International Journal of Humanities and Cultural Studies (IJHCS), 1(2), 24-42.

Al Salem, M. N. (2014). The translation of metaphor from Arabic to English in selected poems of Mahmoud Darwish with a focus on linguistic issues. University of Leeds.

Ayasrah, M. A., \& Azmi, M. N. L. (2019). Intertextuality Between T. S Eliot and Al Sayyab's Poetry. International Journal of English Linguistics, 9(3). https://doi.org/10.5539/ijel.v9n3p78

Bell, R. (1991). Translation and Translating: Theory and Practice. London and New York: Longman.

Dagut, M. (1987). More about the translatability of metaphor. International Journal of Translation. https://doi.org/10.1075/babel.33.2.06dag

Den Broeck, R. (1981). The Limits of Translatability Exemplified by Metaphor Translation. Poetics Today, 2(4), 73-87. https://doi.org/10.2307/1772487

El-Enany, R. (2000). The Quest for Justice in the Theatre of Alfred Farag: Different Moulds, One Theme. Journal of Arabic Literature, 31(2), 171-202. https://doi.org/10.1163/157006400X00043

Karpińska, P. (2017). Computer Aided Translation-possibilities, limitations and changes in the field of professional translation. The Journal of Education, Culture, and Society, 2, 133-142. https://doi.org/10.15503/jecs20172.133.142

Larson, M. L. (Ed.). (1991). Translation: theory and practice, tension and interdependence. John Benjamins Publishing. https://doi.org/10.1075/ata.v

Manipuspika, Y. (2018). Analyzing Translation of Metaphor: A Case Study. Studies in Linguistics and Literature, 2(1). https://doi.org/10.22158/sll.v2n1p1 
Monti, E. (2006). Dwelling upon Metaphors: The translation of William Gass's novellas. NJES: Nordic Journal of English Studies, 5(1), 119-134 https://doi.org/10.35360/njes.50

(n.d.). Retrieved from http://www.mnaabr.com/vb/showthread.php?t=953

Newmark, P. (1981). Approaches to Translation. Oxford; New York: Pergamun Press.

Newmark, P. (1991). About Translation. Clarendon and Philadelphia: Multingual Matters Ltd.

Nida, E. A., \& Taber, C. R. (2003). The theory and practice of translation (Vol. 8). Brill.

Nsiri, I. (2018). Translation and the Quest for Meaning: Adūnīs and Yūsuf al-Khāl's Translation of TS Eliot's The Waste Land. Retrieved from http://hdl.handle.net/11073/16399

Obeidat, H. (1997). Aspects of the problems of translating Metaphor, with Specific Reference to Modern Arabic Poetry. University of St. Andrews

Post-Postmodernism, M. (2015, December 04). The Philosophy of Dance. Retrieved from https:/modernitysite.wordpress.com/2015/12/04/the-philosophy-of-dance/

Spinolo, N. (2018). Studying Figurative Language in Simultaneous Interpreting: The IMITES (Interpretación de la Metáfora Entre ITaliano y ESpañol) Corpus. Making Way in Corpus-based Interpreting Studies, 133-155. Springer, Singapore. https://doi.org/10.1007/978-981-10-6199-8_8

\section{Copyrights}

Copyright for this article is retained by the author, with first publication rights granted to the journal.

This is an open-access article distributed under the terms and conditions of the Creative Commons Attribution license (http://creativecommons.org/licenses/by/4.0/). 